\title{
DIABETIC FOOT SELF CARE PADA DIABETISI
}

\author{
Defrima Oka Surya ${ }^{1 *}$, Zulham Efendi², Afrizal $^{3}$, Ria Desnita $^{4}$ \\ ${ }^{1}$ Program Studi DIII Keperawatan, STIKes MERCUBAKTIJAYA Padang, Jalan Jamal \\ Jamil Pondok Kopi, Siteba, Padang, Sumatera Barat - Indonesia \\ ${ }^{2,3,4}$ Program Studi SI Keperawatan, STIKes MERCUBAKTIJAYA Padang, Jalan Jamal \\ Jamil Pondok Kopi, Siteba, Padang, Sumatera Barat - Indonesia \\ Email Korespondensi: defrima.okasurya@gmail.com
}

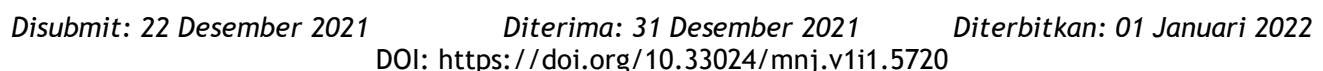

\begin{abstract}
DIABETIC FOOT SELF CARE ON DIABETES PATIENTS
Background : Diabetes Mellitus (DM) can cause complications in various body systems. One of the complications of DM is complications in the feet which can cause diabetic foot ulcers and lead to leg amputation. Diabetic foot complications can be prevented by performing routine foot care or diabetic foot care.

Objective : The purpose of this study was to determine the description of diabetic foot care in patients with diabetes mellitus consisting of personal self care, podiatric care, and footwear and socks.

Method : This type of research is descriptive quantitative research. Data was collected using a diabetic foot care questionnaire. The number of samples in this study were 51 people. The sampling method is a non-probability technique using consecutive sampling. The study was conducted in the Kuranji Health Center Working Area in July - November 2021.

Result : The results showed that most respondents (64.70\%) had poor personal self care in foot care, $82.3 \%$ of respondents had poor podiatric care habits. and $52.94 \%$ of respondents have good habits in choosing footwear.

Conclusion : From the results of the study, it was concluded that people with diabetes have bad habits in performing foot care so that this is one of the risk factors for complications in the feet. To increase awareness of people with diabetes in performing foot care, it is recommended that nurses can provide education and teach people with diabetes to take care of their feet
\end{abstract}

Keywords: Diabetes Mellitus; Foot Complications; Foot Care

\section{INTISARI : DIABETIC FOOT SELF CARE PADA DIABETISI}

Latar Belakang : Diabetes Melitus (DM) dapat menyebabkan komplikasi pada berbagai sistem tubuh. Salah satu komplikasi DM adalah komplikasi pada kaki yang dapat menimbulkan ulkus kaki diabetik dan berujung dengan amputasi kaki. Pencegahan komplikasi pada kaki dapat dilakukan diabetisi dengan melakukan perawatan kaki rutin atau diabetic foot care. 
Tujuan : Tujuan penelitian ini adalah untuk mengetahui gambaran diabetic foot care pada pasien diabetes melitus yang terdiri dari personal self care, podiatric care, serta footwear and sock.

Metode : Jenis penelitian ini adalah penelitian deskriptif kuantitatif. Pengumpulan data dilakukan menggunakan kuesioner diabetic foot care. Jumlah sampel dalam penelitian ini adalah 51 orang. Metode pengambilan sampel adalah dengan Teknik non probability dengan menggunakan consecutive sampling. Penelitian dilakukan di Wilayah Kerja Puskesmas Kuranji pada Bulan Juli - November 2021.

Hasil : Hasil penelitian menunjukkan bahwa sebagian besar responden $(64,70 \%)$ memiliki personal self care yang kurang baik dalam perawatan kaki, 82,3\% responden memiliki kebiasan podiatric care yang kurang baik dan 52,94\% responden memiliki kebiasaan baik dalam pemilihan alas kaki.

Kesimpulan : Diabetisi memiliki kebiasaan yang kurang baik dalam melakukan perawatan kaki sehingga ini menjadi salah satu faktor resiko terjadinya komplikasi pada kaki. Untuk meningkatkan kesadaran diabetisi dalam melakukan perawatan kaki disarankan perawat dapat memberikan edukasi dan mengajarkan diabetisi untuk melakukan perawatan kaki

Kata Kunci : Diabetes Melitus; Komplikasi Kaki; Perawatan Kaki

\section{PENDAHULUAN}

Diabetes melitus (DM) adalah salah satu gangguan metabolik akibat pankreas tidak memproduksi cukup insulin atau tubuh tidak dapat menggunakan insulin yang telah diproduksi secara efektif, yang ditandai dengan adanya peningkatan konsentrasi glukosa darah serta biasanya disertai dengan munculnya gejala utama yang khas, seperti terbuangnya glukosa bersama dengan urin atau dikenal dengan glukosuria (Kemenkes RI, 2014). DM tipe 2 adalah gangguan metabolik yang ditandai dengan hiperglikemia atau tingginya kadar gula dalam darah dan gangguan metabolisme karbohidrat, protein dan lemak yang diakibatkan oleh resistensi insulin (American Diabetes Association, 2015). DM tipe 2 merupakan diabetes yang tidak tergantung pada insulin. DM ini terjadi akibat adanya penurunan sensitivitas terhadap insulin yang disebut dengan resistensi insulin atau akibat penurunan jumlah produksi insulin (Black \& Hawks, 2014).

Kejadian DM tipe 2 mencapai 9095\% dari populasi dunia yang menderita DM (ADA, 2017). Secara global sekitar 425 juta $(8,8 \%)$ orang di seluruh dunia diperkirakan menderita DM tipe 2. Diperkirakan penderita DM tipe 2 usia 20-79 tahun di Indonesia sebanyak 10,3 juta jiwa (IDF, 2017). Menurut Riskesdas tahun 2013 prevalensi DM di Sumatera Barat yaitu 1,3\% dan meningkat pada tahun 2018 menjadi 1,6\% (RISKESDAS, 2018). Dinas Kesehatan Sumbar mencatat tahun 2018 sebanyak 245,105 atau 13,72\% masyarakat menderita DM. Kejadian DM di Kota Padang menurut Dinas Kesehatan Kota Padang (2019) ditemukan penderita Diabetes Melitus sebanyak 17,017 orang. Sedangkan di Wilayah Kerja Puskesmas Andalas Padang ditemukan kasus DM yaitu sebanyak 1,557 kasus pada tahun 2019, dan selama pandemi COVID-19 terhitung Maret sampai dengan Juni 2020, terjadi penambahan yang 
signifikan yaitu sebanyak 1223 kasus Diabetes Melitus (Dinas Kesehatan Kota Padang, 2020).

Kelompok Diabetisi termasuk ke dalam kelompok populasi rentan (vulnerable). Kelompok vulnerable adalah kelompok tertentu di komunitas yang memiliki kemungkinan timbulnya masalah kesehatan lebih besar dari kelompok lainnya (Stanhope \& Lancaster, 2016). Masalah kesehatan pada kelompok vulnerable bisa terjadi akibat adanya keterbatasan fisik, keterbatasan dukungan sosial, keterbatasan ekonomi, serta adanya penyakit (Stanhope \& Lancaster, 2016). Perubahan status fisik akibat penyakit DM menyebabkan individu lebih rentan untuk terjadi penurunan status kesehatan yang disertai dengan komplikasi DM.

DM dapat menyebabkan komplikasi pada berbagai sistem tubuh. Salah satu komplikasi DM adalah terjadinya komplikasi pada kaki. Hasil penelitian Gemechu, Seemant, dan Curley (2013) menyebutkan luka kaki diabetik merupakan penyebab utama adanya hospitalisasi pada pasien DM dibandingkan dengan komplikasi lain. Chow, Lemos, dan Einarson (2008) menyatakan lebih dari 50\% kejadian amputasi non traumatik kaki terjadi pada pasien DM dan lebih dari $85 \%$ dicetuskan oleh ulkus diabetikum yang sudah disertai infeksi. Komplikasi kaki terjadi akibat kombinasi gangguan makrovaskuler dan mikrovaskuler sehingga terjadi risiko injuri yang berlanjut ke proses infeksi yang serius dan akhirnya harus dilakukan amputasi. Lebih dari setengah amputasi ekstremitas bawah nontraumatik berhubungan dengan perubahan karena diabetes seperti neuropati sensorik dan otonom, penyakit vaskuler perifer, peningkatan risiko dan laju infeksi dan penyembuhan yang tidak baik (Black \& Hawks, 2010).

Neuropati sensorik merupakan kematian saraf yang paling berpengaruh terhadap hilangnya sensasi proteksi pada kaki. Neuropati sensorik menyebabkan penurunan sensitivitas kaki. Sekitar 60-70\% Diabetisi mengalami neuropati sensorik dengan penurunan sensitivitas kaki (Lemone \& Burke, 2008). Penurunan sensitivitas kaki yang ditandai dengan adanya kebas, mati rasa di kaki menyebabkan orang dengan neuropati beresiko mengalami trauma atau cidera yang tidak disadari di kaki sehingga berlanjut pada infeksi kaki (Frykberg et al., 2006). Neuropati sensorik dengan penurunan sensitivitas kaki dapat menimbulkan komplikasi luka kaki diabetik (Lemone \& Burke, 2008). Komplikasi berupa luka kaki diabetik akan berdampak pada penurunan kemampuan fisik, pikologis dan sosial ekonomi bagi individu dan keluarganya (Arisman \& Suyono, 2000).

Perawat komunitas sebagai pemberi asuhan keperawatan berperan terhadap upaya meningkatkan kesehatan Diabetisi melalui berbagai intervensi. Berbagai komplikasi masalah kaki diabetik dapat dicegah saat pada fase awal melalui upaya promotif, preventif tanpa mengabaikan upaya kuratif salah satunya adalah dengan melakukan perawatan kaki. Perawatan kaki dapat dilakukan secara mandiri ataupun dengan bantuan keluarga pasien di rumah yang dikenal dengan istilah foot selfcare (Marques, DeSousa, Silvino, \& Lucas, 2014). Perawatan kaki yang bersifat preventif mencakup 3 domain perawatan kaki meliputi personal self- 
care, podiatric care, dan footwear and socks. Hasil penelitian (Ashari \& Kusumaningrum, 2020) menemukan bahwa hanya $52,7 \%$ diabetisi yang melakukan foot self-care dengan baik dengan total diabetisi yang terlibat dalam penelitian adalah 112 pasien. Selain itu, penelitian sebelumnya oleh Li et.al. di Cina juga menunjukkan bahwa perawatan kaki yang dilakukan oleh penyandang DM dikatakan masih cenderung rendah. Sebanyak 70,90\% dari 5961 penyandang DM memiliki tingkat pengetahuan yang baik, namun hanya $41 \%$ yang menerapkan perawatan kaki secara mandiri (Li et al., 2014).

Berdasarkan survey awal pada 5 orang diabetisi di Wilayah Kerja Puskesmas Kuranji diketahui diabetisi sering mengalami kebas pada kaki dan penurunan sensitivitas kaki. Diabetisi sudah melakukan foot self-care sebatas pengetahuannya seperti merendam kaki. Namun, tidak semua tepat dan rutin dalam melaksanakan foot self-care tersebut. Untuk itu, peneliti tertarik untuk mengetahui lebih dalam bagaimana gambaran pelaksanaan foot self-care pada diabetisi di Wilayah Kerja Puskesmas Kuranji Padang sehingga nanti dapat memberikan rekomendasi dan intervensi mengenai foot self-care untuk pencegahan lanjut komplikasi kaki diabetik.

\section{METODE PENELITIAN}

Jenis penelitian ini adalah penelitian kuantitatif, dengan desain penelitian deskriptif. Variabel yang digambarkan pada penelitian ini adalah diabetic foot self care pada diabetisi yang terdiri dari personal self-care, podiatric care, dan footwear and socks. Pengumpulan data dilakukan menggunakan kuesioner diabetic foot care of the
University of Malaga (DFSQ-UMA). Jumlah sampel dalam penelitian ini adalah 51 orang. Metode pengambilan sampel adalah dengan teknik non probability dengan menggunakan consecutive sampling. Adapun kriteria inklusi penelitian ini adalah bersedia menjadi responden, pasien DM tipe 2. Kriteria eksklusi penelitian ini adalah pasien yang mengalami gangguan komunikasi dan tidak bisa baca tulis, pasien dengan ulkus pada kaki.

Penelitian dilakukan di Wilayah Kerja Puskesmas Kuranji pada Bulan Juli - November 2021.

\section{HASIL}

Gambaran karakteristik responden pada penelitian ini dapat dilihat pada tabel 1 berikut.

Tabel 1. Karakteristik Pasien Diabetes Melitus Tipe 2 di Wilayah Kerja Puskesmas Kuranji Padang $(n=51)$

\begin{tabular}{|c|c|c|}
\hline No & Karakteristik & Mean \\
\hline 1 & Usia & 44,28 \\
\hline 2 & $\begin{array}{l}\text { Lama menderita } \\
\text { DM }\end{array}$ & 4,7 \\
\hline 3 & Kadar GDS & 204,5 \\
\hline No & Karakteristik & Frekuensi \\
\hline \multirow[t]{3}{*}{4} & Jenis Kelamin & \\
\hline & Perempuan & $58,82 \%$ \\
\hline & Laki-laki & $41,17 \%$ \\
\hline \multirow[t]{4}{*}{5} & $\begin{array}{l}\text { Tingkat } \\
\text { Pendidikan }\end{array}$ & \\
\hline & Tinggi & $17,65 \%$ \\
\hline & Menengah & $76,47 \%$ \\
\hline & Dasar & $5,88 \%$ \\
\hline
\end{tabular}

Berdasarkan tabel 1 di atas dapat dilihat bahwa rata-rata usia responden penelitian adalah 44,28 tahun, rata-rata lama menderita DM adalah 4,7 tahun dan rata-rata kadar glukosa darah sewaktu adalah 204,5 gr/dl. Sedangkan jika dilihat dari karakteritik jenis kelamin, sebagian 
besar responden berjenis kelamin perempuan $(58,82 \%)$ dan sebagian besar responden memiliki tingkat Pendidikan menengah $(76,47 \%)$.

Gambaran kebiasaan perawatan kaki yang dilakukan oleh responden berdasarkan hasil wawancara terpimpin menggunakan kuesioner diabetic foot care of the University of Malaga (DFSQ-UMA) dapat dilihat pada tabel 2 berikut.

Tabel 2. Gambaran Kebiasaan Perawatan Kaki pada Pasien Diabetes Melitus Tipe 2 di Wilayah Kerja Puskesmas Kuranji Padang $(n=51)$

\begin{tabular}{|c|c|c|}
\hline No & $\begin{array}{c}\text { Diabetic Foot } \\
\text { Care }\end{array}$ & Frekuensi \\
\hline \multirow[t]{3}{*}{1} & $\begin{array}{l}\text { Personal self- } \\
\text { care }\end{array}$ & \\
\hline & Baik & 35,30 \\
\hline & Kurang Baik & 64,70 \\
\hline \multirow[t]{3}{*}{2} & Podiatric care & \\
\hline & Baik & 17,70 \\
\hline & Kurang Baik & 82,30 \\
\hline \multirow[t]{3}{*}{3} & $\begin{array}{l}\text { Footwear and } \\
\text { socks }\end{array}$ & \\
\hline & Baik & 52,94 \\
\hline & Kurang Baik & 47,06 \\
\hline
\end{tabular}

Hasil penelitian pada tabel 2 menunjukkan bahwa sebagian besar responden $(64,70 \%)$ memiliki personal self care yang kurang baik dalam perawatan kaki, $82,3 \%$ responden memiliki kebiasan podiatric care yang kurang baik dan 52,94\% responden memiliki kebiasaan baik dalam pemilihan alas kaki.

\section{PEMBAHASAN}

Self-care menurut WHO adalah segala upaya peningkatan status kesehatan, pencegahan penyakit, stabilitas untuk mengatasi kesakitan dan kecacatan yang dilakukan oleh seseorang, keluarga, sekelompok orang, dengan atau tanpa pendampingan dari penyedia pelayanan kesehatan. Salah satu selfcare pengelolan DM yang dapat mencegah terjadinya komplikasi DM adalah foot self-care. Perawatan kaki atau foot self-care pada diabetisi akan mencegah atau mengurangi terjadinya komplikasi kronik pada kaki. Perawatan kaki adalah suatu tindakan yang dilakukan individu baik dalam keadaan kadar gula normal atau naik yang dilakukan secara teratur untuk menjaga kebersihan diri, terutama pada bagian kaki. Foot self-care adalah aktivitas yang dilakukan oleh diabetisi untuk manajemen perawatan kaki dalam mengurangi resiko ulkus kaki (Ashari \& Kusumaningrum, 2020).

Hasil penelitian menunjukkan bahwa sebagian besar responden $(64,70 \%)$ memiliki personal self care yang kurang baik dalam perawatan kaki. Menurut Nafarro-Flores et al. (2014) personal self care mencakup tentang bentuk perawatan kaki yang harus dilakukan oleh diabetesi setiap hari untuk mencegah terjadinya komplikasi atau ulkus kaki diabetik. Aktivitas meliputi memeriksa kaki secara rutin setiap hari, menjaga kebersihan kaki, pemeriksaan rutin kuku kaki, pemotongan rutin kuku kaki dan pengeringan kaki. Personal self care yang buruk dapat meningkatkan resiko komplikasi kaki pada diabetisi.

Menurut The Centers for Disease Control and Prevention bahwa perawatan kaki secara teratur dapat mengurangi penyakit kaki diabetik sebesar $50-60 \%$ yang mempengaruhi kualitas hidup. Diabetisi sebaiknya mengetahui dan mempunyai niat yang tinggi dalam melakukan perawatan kaki karena perawatan kaki diabetik dilakukan secara teratur sehingga akan mendapatkan kualitas hidup yang baik. Pemeriksaan dan perawatan kaki 
diabetes merupakan semua aktivitas khusus (memeriksa dan merawat kaki) yang dilakukan individu yang beresiko sebagai upaya dalam mencegah timbulnya komplikasi neuropati seperti ulkus diabetikum.

Hasil penelitian juga menunjukkan bahwa $82,3 \%$ responden memiliki kebiasan podiatric care yang kurang baik. Pada domain podiatric care meliputi masalah yang sering dialami oleh panyandang DM dalam melakukan perawatan kaki yaitu kesulitan dalam pemilihan alas kaki yang nyaman, kesulitan dalam pemilihan alas kaki yang nyaman, penanganan terhadap kulit kaki yang kasar atau kalus pada kaki, informasi atau rekomendasi perawatan kaki yang dilakukan secara mandiri (Nafarro-Flores et al., 2014).

Domain podiatric care mencakup bentuk kesulitan yang sering dialami oleh diabetisi dalam melakukan perawatan kaki termasuk dalam penanganan kalus dan luka serta informasi mengenai perawatan kaki yang tepat dari tim ahli. Hasil penelitian Hanif (2015) menunjukkan bahwa sebagian besar diabetisi 40,7\% menunjukkan ketidakadekuatan dalam penanganan kulit kering atau kalus pada kaki.

Aspek ini menggambarkan kesulitan dan kendala yang dialami penyandang DM dalam melakukan perawatan kaki. Persepsi penyandang DM terhadap pentingnya melakukan foot self-care secara rutin sangat baik. Hal tersebut dibuktikan dengan persentase yang sama oleh penyandang DM yang menjawab sangat penting dan penting tentang urgensi foot self-care ini. Namun di sisi lain masih cukup banyak pula penyandang DM yang tidak mendapatkan informasi dan tidak tahu cara merawat kaki. Maka dari itu edukasi tentang perawatan kaki masih perlu untuk diberikan agar penyandang DM paham, dan dapat melaksanakan perawatan dengan baik, dan teratur serta, sebagai media penyandang DM untuk mendapatkan motivasi, dan dukungan emosinal (Ashari \& Kusumaningrum, 2020).

$\begin{array}{ccc}\text { Hasil } & \text { penelitian } & \text { juga } \\ \text { menunjukkan } & \text { bahwa } & 52,94 \%\end{array}$ responden memiliki kebiasaan baik dalam pemilihan alas kaki. Domain kebiasaan dalam pemilihan alas kaki dikenal dengan istilah footwear and socks. Tindakan perawatan pada domain ini meliputi cara pemilihan alas kaki dan kaos kaki yang digunakan yaitu: pemilihan kaos kaki, pemeriksaan sepatu sebelum dipakai, pemakaian sepatu, pemilihan sepatu untuk musim kemarau atau di saat cuaca panas dan cara menghangatkan kaki (Nafarro-Flores et al., 2014).

\section{KESIMPULAN}

Sebagian besar diabetisi masuk dalam kategori kuranng baik dalam melakukan foot self-care. Bagi Puskesmas dan perawat komunitas, perlu adanya peningkatan edukasi bagi diabetisi tentang foot self-care terutama tentang pemeriksaan kaki, penggunaan pelembab, dan kaos kaki, serta cara menghangatkan kaki. Peneliti lain diharapkan melakukan penelitian lanjutan mengenai keefektifan foot self-care untuk mencegah terjadinya ulkus kaki dengan metode kuesioner dan observasi.

\section{DAFTAR PUSTAKA}

ADA. (2017). Standards of Medical Care in Diabetes. Diabetes Care.

American Diabetes Association. (2015). Classification and diagnosis of diabetes. Sec. 2. 
In Standards of Medical Care in Diabetes 2015. Diabetes Care 2015.

Ashari, A. M., \& Kusumaningrum, N. S. D. (2020). Foot Self-Care Pada Penyandang Diabetes Mellitus (DM) : Pilot Study di Semarang. Journal of Islamic Nursing, 5(1), 54-59.

Black, J. M., \& Hawks, J. H. (2014). Keperawatan Medikal Bedah: Manajemen Klinis untuk Hasil yang Diharapkan. Alih Bahasa Edisi 8 (Edisi 8). Salemba Medika.

Ernawati. (2013). Penatalaksanaan Keperawatan Diabetes Melitus Terpadu. Mitra Wacana Media.

I Made Sudarma Adiputra, I Made Dwi Arianita, N. W. T. (2020). Ankle Brachial Index berhubungan dengan Sensitivitas Kaki pada Penderita Diabetes Mellitus Tipe II. Jurnal Ilmiah Keperawatan Sai Betik, 16(1), 183-191.

IDF. (2017). Diabetes Atlas Eighth edition 2017. In International Diabetes Federation. IDF Diabetes Atlas, 8th edn. Brussels, Belgium: International Diabetes Federation, 2017. http: / / www. diabetesatlas.o rg.

Kemenkes RI. (2014). Situasi Dan Analisis Diabetes Melitus. Kementrian Kesehatan Republik Indonesia.

Navarro-Flores E, Morales-Asencio JM, Cervera-Marin JA, LabajosManzanares MT, GijonNogueron G. Development, validation and psychometric analysis of the diabetic foot self care questionnaire of the
University of Malaga, Spain (DFSQ-UMA). Journal of Tissue Viability [Internet]. 2014 Nov 27 [cited 2016 Dec 7], Available from: http: / /www.ncbi.nlm.nih.go v/pubmed/25523014

RISKESDAS. (2018). Hasil Utama Riskesdas Tentang Prevalensi Diabetes Mellitus di Indonesia 2018. Hasil Utama Riskesdas Tentang Prevalensi Diabetes Melitus Di Indonesia 2018.

Stanhope, M., \& Lancaster, J. (2016). Public health nursing population centered health care in the community. Elsevier.

Sugiyono. (2013). Metode Penelitian Pendidikan Pendekatan Kuantitatif, Kualitatif. Alfabeta, Bandung.

Sugiyono. (2018). Metode Penelitian Manajemen (Setiyawami (ed.); 6 Th). Alfabeta,Bandung.

Wahyudi, I. (2019). Hubungan Lama Menderita Diabetes Melitus Dan Kadar Glukosa Darah Sewaktu dengan Tingkat Sensitivitas Kaki di Puskesmas Pahandut Palangkaraya. Politeknik Kesehatan Kemenkes Palangkaraya.

Zainaro, M. A., Djamaludin, D., Gunawan, M. R., Susmarini, N., \& Malahayati, A. K. (2018). Pemeriksaan, Perawatan Dan Senam Pada Lansia Dengan Diabetes Mellitus Di Upt Puskesmas Kota Bumi Lampung Utara Tahun 2017. Jurnal Kreativitas Pengabdian Kepada Masyarakat, 1(1). 